\title{
Preserved honey bee health in Latin America: a fragile equilibrium due to low-intensity agriculture and beekeeping?*
}

\author{
Rémy VANDAME ${ }^{1}$, María Alejandra Palacio ${ }^{2}$ \\ ${ }^{1}$ El Colegio de la Frontera Sur, Carretera Panamericana y Periférico Sur S/N, Barrio María Auxiliadora, \\ 29230 San Cristóbal de las Casas, Chiapas, Mexico \\ ${ }^{2}$ Unidad Integrada INTA - Facultad de Ciencias Agrarias, Universidad Nacional de Mar del Plata, CC 276, \\ 7600 Balcarce, Argentina
}

Received 6 October 2009 - Revised 4 February 2010 - Accepted 13 February 2010

\begin{abstract}
The Latin American subcontinent contains some of the world's major honey producing and exporting countries, but the status of bee health in this part of the world has not been clearly documented. There have been no reports of massive colony losses in Latin America, at least from the symptoms of CCD (colony collapse disorder) or in the proportion and extent of the situations in the US and Europe. We examine possible reasons for the difference, and develop hypotheses that this prevailing good bee health could be due to: (1) the management of generally unselected bees with a certain natural resistance to diseases (tropical regions) or the selection of disease resistant bees (temperate regions); (2) a lower proportion of cropland over the total land area, resulting in more abundant or higher-quality pollen resources for bees; (3) the generally small-scale, low-income and little subsidized agriculture, and concomitant lower use of insecticides compared to industrialized countries. These general parameters may act synergistically, resulting in a large number of configurations across the tremendous ecological, social and economic diversity of Latin America. We suggest that the health of honey bees in Latin America may be ultimately due to the practices of low-income agriculture and beekeeping in the region, leading to more sustainable conditions for the bees. However the increasing trend of land use intensification in some parts of Latin America could lead to declines in honey bee health and population size.
\end{abstract}

honey bee health / colony losses / disease resistance / genetic diversity / pollen nutrition

\section{INTRODUCTION}

Losses of honey bee (Apis mellifera L.) colonies have been documented repeatedly during the last years in Europe (Neumann and Carreck, 2010) and in the United States (van Engelsdorp et al. 2008, 2009). Colony mortality characterized by rapid loss of adult worker bees was named colony collapse disorder (CCD) (van Engelsdorp et al., 2009). But there is little data on similar symptoms of bee losses outside of these areas, including Latin

Corresponding author: R. Vandame, remy@ecosur.mx

* Manuscript editor: Marla Spivak
America (LA). Countries like Argentina and Mexico have a strong beekeeping tradition, and are among the world's largest honey producers (ranking 2nd and 6th, respectively) and exporters (1st and 3rd respectively; FAOSTAT, 2009). Therefore it is interesting to focus on the LA region to determine if colony losses have been reported.

In this paper we first state that no massive losses due to symptoms described for CCD have been documented to date in LA. Therefore we attempt to determine possible reasons for differences between what is occurring in the US and bee losses in Europe compared to LA. We structure our observations 
by examining the four items considered as possible factors responsible for colony loss in the Managed Pollinator Coordinated Agricultural Project (Managed Pollinators CAP, 2008; Pettis and Delaplane, 2010): disease agents (pathogens, parasites) and environmental factors (nutrition, pesticides). We examine if the conditions in LA ameliorate the impact of these factors, and if these conditions could explain the relatively good health of the honey bees in this region. Finally we speculate on the risks that might disrupt the fragile equilibrium of bee health in LA in the future.

\section{PRESENT SITUATION: NO MASSIVE LOSSES OF COLONIES IN LA}

Evaluating the health of honey bees in LA is a difficult task for two reasons. First, this region is large and highly diverse, with beekeeping being practiced over a wide range of climates (from tropical to temperate) and altitudes (from sea level to around $2000 \mathrm{~m}$ altitude), by very different beekeepers (who have from 15 colonies each in Mesoamerica up to 15000 in northern Mexico or the Pampas region of Argentina). Hence it is hard to draw a general picture that can take into account all of this diversity. Second, there is little synthetic information published on honey bee health in different parts of the region.

However, to date, from Mexico to Argentina, there have been no reports of massive colony losses or weakening of colonies due to adult bees losses, such as described by $\mathrm{CCD}$, by official institutions, researchers, or beekeepers professional beekeeping organizations. This situation is the same in Africa, southern Asia and Australia (Neumann and Carreck, 2010). Local problems in various regions of LA are commonly reported however and we will mention some of them here.

For example, for several years beekeepers of southeastern Guatemala have reported significant losses in the months from February to April (flowering season). They place the responsibility on an international control program for the Mediterranean fruit fly (Ceratitis capitata), in which the insecticide
Spinosad is commonly used on a large scale. Edwards et al. (2003) demonstrated toxicity of this compound to honeybees under laboratory conditions, though Mangan and Moreno (2009) showed that honey bees are repelled by the fruit fly attractant components of the commercial product that is used in the field. However, field observations show that apiaries are regularly sprayed with this insecticide, and it appears to be a toxicological problem as reported by beekeepers for many years (Vandame et al., 1995). In the northern state of Chihuahua, Mexico, recurrent losses are described (Arnulfo Ordoñez, unpubl. data) and are still unexplained, but are limited to a local scale.

Beekeepers of Uruguay report frequent declines in honey bee populations in spring, called "Mal de Santa Lucia". Though no factor has been clearly identified (Harriet et al., 2009), this decline seems to be an effect of food shortage in spring, apparently increasing in recent years due to loss of natural vegetation. Losses related to Varroa also have been reported in recent years in Argentina, in particular due to the lack of a generalized Varroa control strategy (Emilio Figini, pers. commun.), mite resistance to coumaphos (Maggi et al., 2009), and in Chile, due to the application of mite control too late in the season (Miguel A. Neira, Universidad Austral de Chile, pers. commun.) or because of nutritional problems. It is also notable that during the last summer, in the northern parts of Chile, where honey bees are used for pollination, thousands of colonies have been lost (Juanse Barros, unpubl. data). This massive mortality is a true cause for concern, but seems to be restricted to areas with intensive agricultural practices, hence generating the suspicion that the losses may be due to toxic effects of pesticides.

The situation is also diverse in Brazil (David de Jong and Dejair Message, unpubl. data). Periodic large-scale die-offs of bees reported for the last 40 years were originally blamed on a local type of sacbrood disease, or some sort of spring dwindle. Now the losses are known to be caused by toxic pollen from native trees in the Cerrado (Savanna-like biome) regions (de Carvalho and Message, 
2004; de Souza et al., 2006). Large-scale losses have become increasingly common in Brazil. Since these losses have been simultaneous to the expansion of crops for agrofuels and the increased use of pesticides, beekeepers tend to attribute these losses to insecticides, especially neonicotinoids, though no evidences have been given. The pesticides affect both honey bees and stingless bees, making beekeeping inviable in some regions. Moreover, Varroa infestation levels are reported to be alarmingly high in the (cooler) southern states of Rio Grande do Sul and Santa Catarina in Brazil, with beekeepers reporting losses. Also it seems that Nosema and Varroa are becoming more problematic than they used to be, though for unknown reasons (Aaroni Sattler, Universidade Federal do Rio Grande do Sul, personal communication), and may be a consequence of the increased use of pesticides that could weaken honey bee immunological or behavioral defenses.

These cases of bee losses, which are likely much more common than what can be found in published reports, either can be attributed to a clear cause or are confined to a local level, and remind us of the problems routinely encountered by the beekeepers worldwide, rather than a CCD-like phenomenon. When they occur on a larger scale, as in Chile or Brazil, they seem to be geographically correlated with more intensive agriculture. In the following sections, we therefore examine some situations that may explain why CCD has not been reported in LA.

\section{UNSELECTED HONEY BEES AND RESISTANCE TO DISEASES}

There is a general consensus that CCD is multifactorial, and research indicates that it may be due to "either increased exposure to pathogens or a reduced resistance of bees toward pathogens" (van Engelsdorp et al., 2009). The introduction of new pathogens and their interaction with already present ones may increase the problems (Eyer et al., 2009). Resistance to pathogens has a strong genetic basis (Rothenbuhler, 1964), and many studies have shown that honey bee colonies vary in their resistance to diseases as common as American foulbrood (AFB; Behrens et al., 2007). However, it is only in the last 20 years that significant work has been done to understand and select for resistance to AFB and chalkbrood diseases in bees (Spivak and Reuter, 1998; Palacio et al., 2000) and to Varroa destructor (Ibrahim et al., 2007; Harbo and Harris, 2009; Fries and Bommarco, 2007; Rinderer et al., 2010).

In turn, very little artificial selection has been done on honey bees in LA. The introduction of the European bee races at different times during the XVIIth century, and of the African bee race in 1956 has resulted in a considerable genetic mixture of Apis mellifera races (Kraus et al., 2007). We now differentiate the situation in tropical and temperate parts of LA to understand a differential resistance to diseases.

Africanized honey bees (AHB) have been successfully established throughout most of tropical LA. Relatively little effort has been made to select these bees, so that there has been little or no reduction in AHB genetic diversity. Hence they can still be considered as mainly unselected bees. Beekeepers working with AHB normally have no AFB problems, very little chalkbrood, and Varroa mites populations in untreated colonies always remain below a critical level (Vandame et al., 2002; Mondragón et al., 2005), even though miticide treatments can help to improve honey production (Guzmán-Novoa et al., 1999). It is worth noting that when only EHB was found in Mexico (i.e. before 1986), AFB and tracheal mites, Acarapis woodi, were significant problems. The disease resistance described above occurred subsequent to AHB invasion (Medina et al., 2006). The strongest hypothesis to explain this resistance is that AHB express a high degree of hygienic behavior, in which the adult bees are able to detect brood cells invaded by a reproducing Varroa mite. We report here unpublished data demonstrating that EHB colonies detect only $18 \%$ of experimentally infested pupae, while a higher percentage of AHB colonies are able to detect mite-infested pupae, up to a maximum of $64 \%$ (Fig. 1).

Africanized bees in Brazil are more resistant to Varroa than European bees, and mite infestations were found to be higher in the 

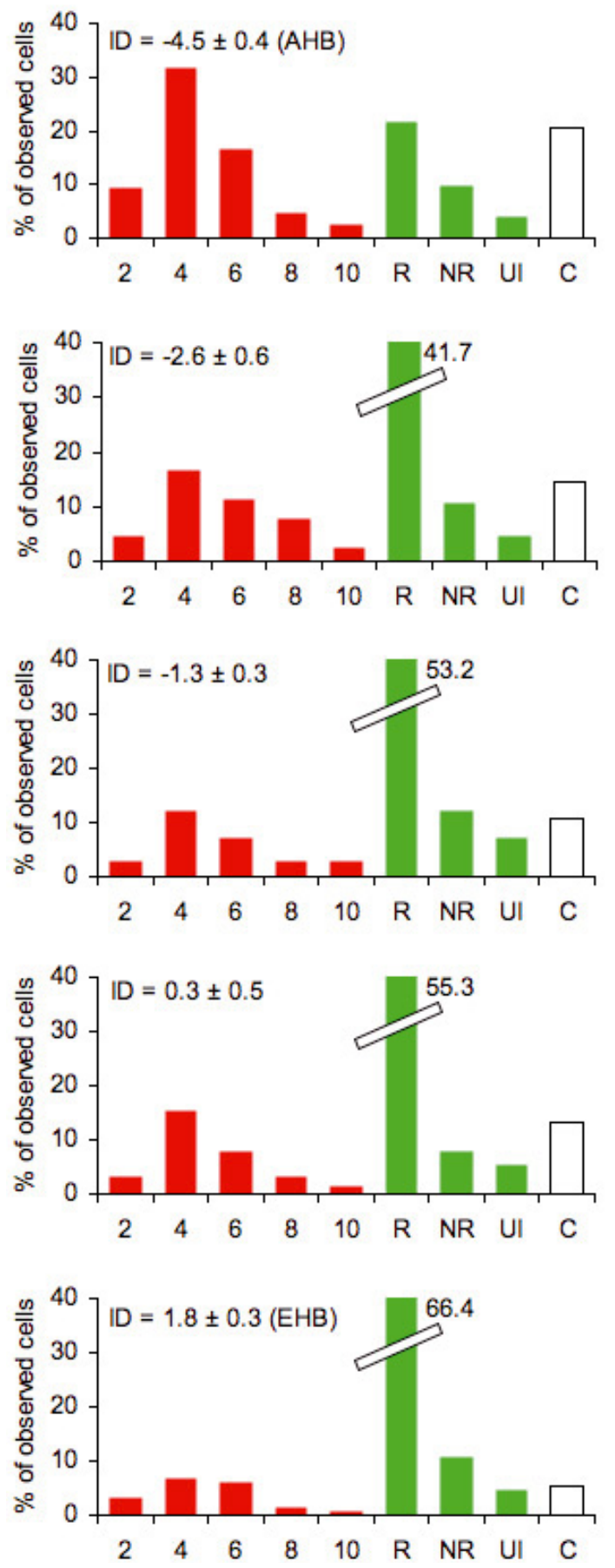

Figure 1. Removal of pupae artificially infested with a Varroa destructor mite in colonies with different Africanization levels. Selection of colonies. The level of Africanization (morphometric analysis) of 60 colonies of beekeepers apiaries was determined following the procedure described by Rinderer et al. (1993). Among them, 25 colonies were chosen for their homogeneous distribution along an AfricanizedEuropean cline, in groups of 5 colonies. The Africanization degree (ID) is the projection on the discriminant function 1 in the multivariate analysis performed by Rinderer et al. (1993) and varies from -6 (most Africanized colonies, top graph) to 4 (most European ones, bottom graph). Artificial infestation. 30 mites were collected from emerging brood (i.e. at a phase when they are able to reproduce) and were introduced into 30 cells containing pupae from the same colonies (to avoid detection for odor of another colony) that had been capped for less than $3 \mathrm{~h}$. Additionally, 30 cells were uncapped and immediately recapped as controls. Determination of removal abilities. The cells containing artificially infested pupae were observed every 2 days over 10 days to determine if the bees removed the pupae. The 10th day, all remaining cells were uncapped to determine if they were still infested, and if so, if the mite inside had reproduced. The figure shows for each 5colony group of colonies from most Africanized (top graph) to least Africanized (bottom graph), the percent of observed pupal cells in each of the following categories: cells uncapped in each 2-day period over 10 days after capping ("2" to "10"); cells in which mites reproduced normally ("R"); cells still capped, but in which mites did not reproduce ("NR"); cells no longer infested ("NI"); control cells uncapped in the first 10 days after capping ("C"). Overall, the more Africanized (i.e. unselected) the colonies, the more they detected pupae containing reproducing Varroa mites. 

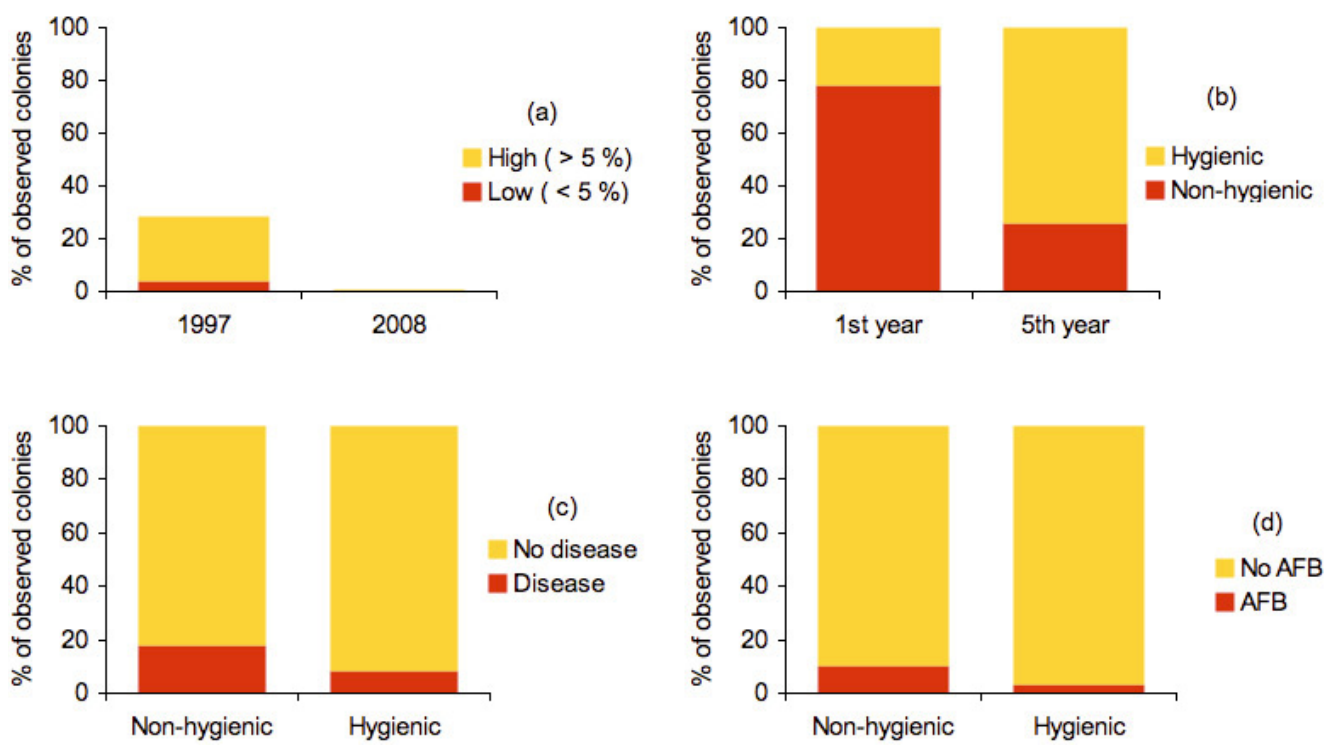

Figure 2. Selection of hygienic colonies for disease resistance in Argentina (adapted from Bedascarrasbure et al., 2009). (a) Percentage of colonies expressing a high or low AFB prevalence in the population in 1997 (2935 colonies observed) and 2008 (9971 colonies observed). (b) Percentage of hygienic and nonhygienic colonies in the population, before the start of the ProApi national selection program and 5 years later. (c) Percentage of colonies with brood diseases in populations of hygienic and non-hygienic colonies. (d) Percentage of colonies with AFB symptoms in populations of hygienic and non-hygienic colonies.

cooler regions when compared to the more tropical parts of Brazil (De Jong et al., 1984). This adaptation is probably a consequence of the bees being infested by the less virulent Japanese type Varroa destructor. However, the Korean mitotype of Varroa destructor was identified in Brazil in the 1990s and it currently is the only type identified throughout the continent. One of the changes in Brazil since the Korean mitotype of Varroa destructor took over has been increased reproduction by the mites. Apparently because of the new type of Varroa, the percentage of female mites that reproduced shifted from about the half (de Jong et al., 1984) to over 80\% (Carneiro et al., 2007).

In temperate LA, where only EHB have established, as in Chile and most areas in Argentina or Uruguay, diseases are more often a problem. This situation is possibly amplified because the populations historically introduced may have been more susceptible to diseases like chalkbrood (Jensen et al., 2009).
However in Argentina, brood diseases are less of a problem than they used to be, due to human intervention (Bedascarrasbure, 2009). AFB was first detected in this country in 1989 , and the genetic selection of local ecotypes with high hygienic behavior was started some years after. Importance was given to disease tolerance, resulting in a bee strain that is now mainly resistant to AFB (Palacio et al., 2000,2005 , in press). We report a synthesis of these results (Fig. 2). Varroa is still a significant problem in most temperate regions in Argentina. Although some alternative and effective acaricides have been developed locally, it is still necessary to use synthetic acaricides but the efficiency of these acaricides is now known to be decreasing (Maggi et al., 2009).

A rare situation is found in the Dominican Republic, where AHB have not invaded, so that it is possible to observe EHB in a tropical climate. Here the population dynamics of Varroa shows patterns similar to the one in Mexico with AHB (Castillo, 2009); i.e., with 
a population increase during most of the year, and a natural decline at the end of the floral bloom period. Since these bees have been established for a long time with very few subsequent introductions, their apparent resistance to Varroa, in common with AHB, seems to be that they have gone through very little selection by the beekeeping industry.

Special mention should be made here to two other types of diseases. One is the microsporidium Nosema ceranae, suspected to be responsible for colony losses in different parts of the world (Paxton et al., 2007; Higes et al., 2010) whose biology is currently being investigated (Naug and Gibbs, 2009; Chen and Huang, 2010). In Brazil, Nosema had not been a problem since the 1960s, after Africanized honey bees took over. However, during the last years, large numbers of Nosema spores have been found in adult bees from colonies that were reported by beekeepers to be weak and dying. $N$. ceranae (and not $N$. apis) was first confirmed to be present in Brazil in 2006 (Klee et al., 2007) and was recently shown to have been present in Uruguay for nearly 20 years, without causing particular damages (Invernizzi et al., 2009), a situation likely to be similar in all LA. The reason for this low pathogenicity can be either the presence of a less virulent strain of the parasite or some resistance trait of the bees.

Other important diseases are the viruses, still relatively unstudied in honey bees (Gauthier et al., 2007). Their prevalence has been shown to be significantly higher in CCD than in control colonies in the US (van Engelsdorp, 2009), though it is still hard to say if such prevalence is a cause or a consequence for CCD. Though little is known about viruses in LA, the few existing studies show that most known viruses are present (Antúnez et al., 2005, 2006), even if it has also been demonstrated that the prevalence of viruses as a whole is lower in Brazil than in the rest of the world (Teixeira et al., 2008). It is therefore possible that the low prevalence of viruses is part of the reason for the preserved health of Latin-American bees.

Overall, honey bee strains managed in LA are either nearly unselected (AHB, EHB in Dominican Republic) or selected for disease resistance (EHB in Argentina), and in most of the countries, especially under temperate climate, there is little use of synthetic treatments to control diseases and mites. Even if there is lower prevalence of diseases in LA compared to the rest of the world, it appears that there also has been natural selection for a certain level of resistance to diseases. This general picture leads us to hypothesize that $\mathrm{CCD}$, or high colony losses, have not been found in LA because the higher level of defense of the bees against diseases reduces at least one of the major risk factors involved in CCD. Such an advantage is threatened however by the common beekeeping practice of illegally introducing queens from foreign countries, instead of promoting selection on local stocks, as is done for example in Europe (de la Rúa et al., 2009; Buechler et al., 2010).

\section{PRESERVED NATURAL VEGETATION AND POLLEN DIVERSITY}

Environmental factors may be responsible for CCD, and in particular deficiencies in pollen nutrition (Brodschneider and Crailsheim, 2010). It has been shown that the quality of spring-reared workers is strongly influenced by the availability of pollen in colonies during larval development (Mattila and Otis, 2006). Furthermore, "pollen nutrition can play an important role in the development of disease because poor nutrition may result in a less robust defense system" (Managed Pollinator CAP, 2008). Fries (1993) showed that good pollen supply reduced infection levels in colonies.

This importance of pollen nutrition may imply that heavily managed landscapes are poor for the sustainability of honey bee colonies, a hypothesis that to be tested requires the development of a specific methodology to qualify landscapes. Some data in the US seem to validate this idea (Naug, 2009), but for LA countries there are no such data published. Thus, we use indirect parameters to compare different regions of the world.

The first parameter is the percentage of original forest remaining, as determined for 


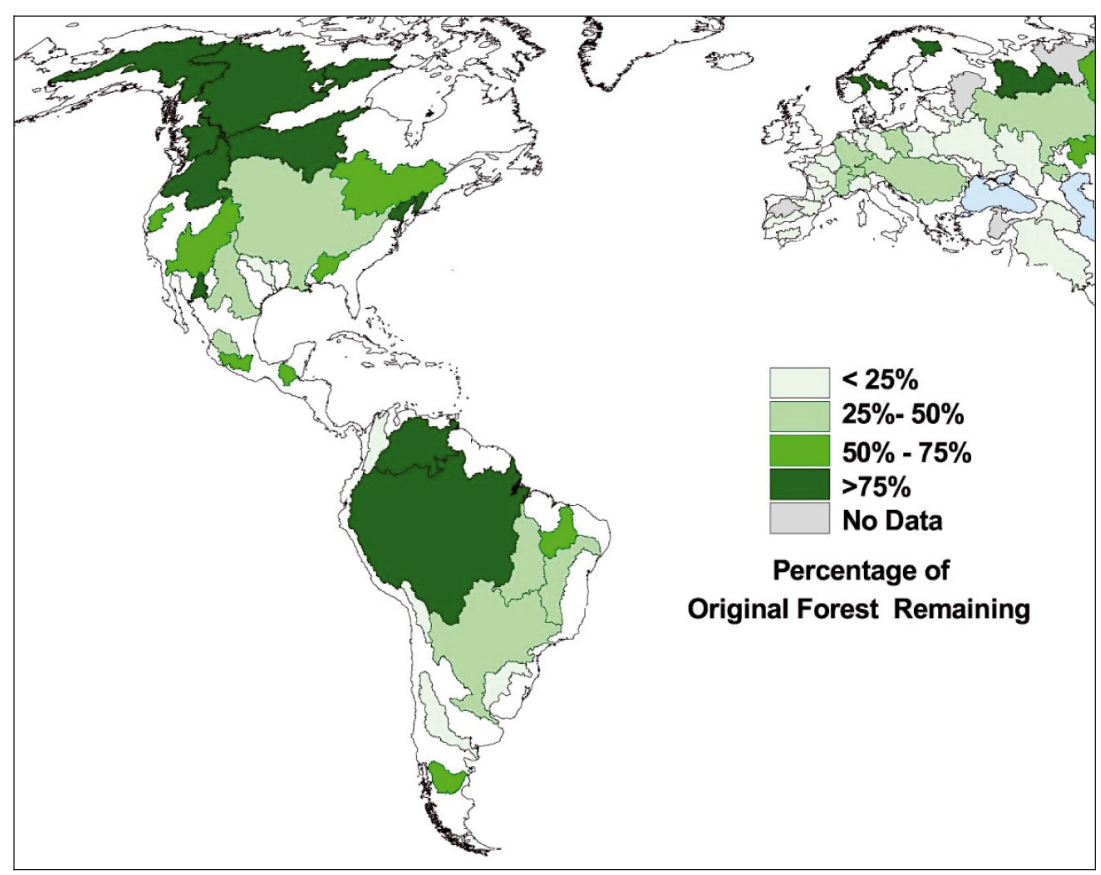

Figure 3. Extract of the Water Resources eAtlas published by the World Resources Institute (2003) (http:// earthtrends.wri.org/maps_spatial/watersheds/global.php) showing the original forest remaining in the main basins in Europe and the Americas.

the main watersheds of the world by the World Research Institute (2003). The quantified (colored) watersheds in the US and Europe are heavily influenced by human management and consequently the forested areas within them occupy less than $50 \%$ and often less than $25 \%$ of their surface (Fig. 3). Though few watersheds are quantified in LA, they appear commonly covered by more than $50 \%$ and sometimes more than $75 \%$ with original forest. Though this is still a very raw analysis, it supports the observation that forest and by extension, natural resources, may be better preserved in LA than in US and Europe. However the percentage of forested areas may not be the best indicator of bee nutrition since forests offer limited resources for bees; a further understanding would require the development of indicators more fitted to honey bee natural history.

The previous consideration is supported by data extracted from EarthTrends (2003) country profiles, synthesized in Table I, showing the fraction of cropland within total land area. In western European countries with strong agriculture, croplands represent around 35\% of the total area. In the US, cropland represents only $19 \%$ of the total area (value lowered by extended uncultivated areas). This percent decreases to $14 \%$ in Mexico, and varies between $3 \%$ and $10 \%$ in South America. Such national level data do not represent the diversity at regional levels, like in the US or in Argentina. However it is clear that land use is much more intense in the US and Europe that in LA, and it is possible that the pollen nutrition in LA is more abundant throughout the year, or of better quality, than in more industrialized countries.

Another indirect factor that could influence bee health is the size of farms. In northern countries, farms tend to be much bigger and are cultivated from end to end, while the situation is reversed throughout most of LA. Small scale farming results in more fragmented landscapes, thus helping to preserve the diversity 
Table I. Summary of statistics on land and pesticide use in some countries of Europe and the Americas, extracted from EarthTrends, the environmental information portal of the World Resources Institute (http:// earthtrends.wri.org) and FAOSTAT of the Food and Agriculture Organization of the United Nations (http:// faostat.fao.org) from September 2009. The insecticide use value is the average of the 1990-2001 data on FAOSTAT. The last column was calculated based on the previous data.

\begin{tabular}{|c|c|c|c|c|c|c|}
\hline & $\begin{array}{l}\text { Total cropland } \\
\quad(1000 \mathrm{ha})\end{array}$ & $\begin{array}{c}\text { Cropland per } 1000 \\
\text { population }\end{array}$ & $\begin{array}{c}\text { Cropland as \% } \\
\text { of total land area }\end{array}$ & $\begin{array}{c}\text { Fertilizer } \\
\text { use }(\mathrm{kg} / \mathrm{ha})\end{array}$ & $\begin{array}{c}\text { Insecticide } \\
\text { use }(T)\end{array}$ & $\begin{array}{r}\text { Insecticide } \\
\text { use }(\mathrm{g} / \mathrm{ha})\end{array}$ \\
\hline Source & EarthTrends & EarthTrends & EarthTrends & EarthTrends & FAOSTAT & Calculated \\
\hline Date & 1999 & 1999 & 1998 & 1999 & 1990-2001 & \\
\hline World & 1501452 & 251 & 11.3 & 94 & 388743 & 259 \\
\hline Europe & 307286 & & & & & \\
\hline Netherlands & 949 & 60 & 23.0 & 501 & 488 & 514 \\
\hline Germany & 12038 & 147 & 33.9 & 252 & 1426 & 118 \\
\hline France & 19515 & 331 & 35.4 & 244 & 6109 & 313 \\
\hline Italy & 11422 & 199 & 37.0 & 155 & 25215 & 2208 \\
\hline Spain & 18530 & 464 & 36.6 & 125 & 9345 & 504 \\
\hline North America & 224703 & & & & & \\
\hline USA & 179000 & 638 & 19.1 & 111 & 102682 & 574 \\
\hline Central America & 43426 & & & & & \\
\hline Mexico & 27300 & 280 & 13.9 & 66 & na & \\
\hline Guatemala & 1905 & 172 & 17.5 & 95 & 234 & 123 \\
\hline Cuba & 4465 & 400 & 40.3 & 33 & na & \\
\hline South America & 116131 & & & & & \\
\hline Brazil & 65200 & 388 & 7.6 & 90 & 15076 & 231 \\
\hline Chile & 2294 & 153 & 3.0 & 207 & 2893 & 1261 \\
\hline Argentina & 27200 & 744 & 9.8 & 30 & 7422 & 273 \\
\hline Uruguay & 1307 & 394 & 7.4 & 103 & 222 & 170 \\
\hline
\end{tabular}

na: not available data.

of plants (i.e. diversity of food for bees) and the abundance of nesting places.

However, in southern countries like Argentina, Brazil and Uruguay, yield-intensive crops have increased in recent years (particularly soy) and this has negatively affected beekeeping through lower pollen availability. Beekeepers and scientists report that the strength of colonies at the end of wintering (early spring) tend to decrease in many areas, and proteins have to be supplied to colonies in some areas with intensive, commercial beekeeping.

We hypothesize that generally smaller scale of agriculture in LA permits a higher diversity of pollen, and thus better pollen nutrition and a lower susceptibility to diseases for the bees. This hypothesis could explain why CCD has not been reported in LA. But if true, then the risks to bee health are slowly increasing due to agricultural intensification.

\section{SMALL SCALE AGRICULTURE, LOW USE OF PESTICIDES AND GMOS}

Another permanent threat for the bees coming from human manipulated environments is the exposure to pesticides used in crop production. For a long time this topic has been a source of conflict between beekeepers and the pesticide industry. There is actually a large amount of data showing that certain pesticides that have no demonstrated lethal effects on honey bees in laboratory conditions do in fact have sublethal (Vandame et al., 1995; Desneux et al., 2007) or synergistic effects (Vandame and Belzunces, 1997). Since they may alter 
bees development, adult longevity, mobility, navigation, orientation, feeding behavior or learning, they could explain the common CCD observation that affected foragers fail to return to their nest (Managed Pollinator CAP, 2008).

In general, intensive crops are less abundant in LA, but again, it is rather difficult to compare pesticide use in Europe, US and LA. We have reported that croplands represent a much higher proportion of the total land area in industrialized countries compared to in LA (as a whole) (Tab. I). Furthermore, EarthTrends (2003) data show that fertilizer use is about twice as high in western Europe compared to the US or LA. The pesticide statistics are more interesting since these compounds may affect bees more directly. According to FAOSTAT (2009) data, the insecticide use per unit of area is roughly twice as high in the US and in Europe than in LA (except in Chile, where data are probably influenced by vineyard data), a situation derived from the high level of subsidized agriculture by the EU and the US (Mayrand et al., 2003; Pearce, 2002). Unfortunately, since these statistics are based on voluntary information provided to FAO by the countries, the data are not completely reliable or comparable, nor are they detailed about compounds used such as imidacloprid (Guez et al., 2001). However, the data do show a clear trend of lower use of insecticides in LA. Even a locally intensive insecticide use would have a rather local effect, thus having no general impact.

The effect of genetically modified (GM) crops on honey bees is a controversial but little studied topic. Though one study and a recent meta-analysis showed that Bt crops had no effect on honey bee survival (Rose et al., 2007; Duan et al., 2008), a different study showed some impact on feeding behavior and learning performances of worker bees (RamirezRomero et al., 2008).

There are few data on the extent of GMO crops. They are permitted only at very small scale in Europe but are exceptionally common in the US, in particular GM-corn, but their use seems to be very limited in LA, except for the notable exception of GM-soy in Argentina, Brazil and Uruguay. Though they are also banned in Mexico, the presence of trans- genes in the Mexican maize (Piñeyro-Nelson et al., 2009) has been reported. This is a type of genetic pollution that clearly affects biodiversity, but probably has no direct effect on bee health.

Overall, it seems that small scale agriculture has protected honey bees, due to low exposure to chemical contaminants, which could be a third reason why CCD has not been reported in LA. There are however some changes in the practices that could convert to threats, like the continuous extension of GM crops in Argentina and Brazil, or the increasing use of insecticides in all countries. Currently in Argentina, the strength of honey bee colonies in spring is decreasing each year, thus requiring more intensive feeding. This occurrence could be a signal of forthcoming problems.

\section{A FRAGILE EQUILIBRIUM}

Overall, the factors most often considered responsible for $\mathrm{CCD}$ in the US or for colony losses in Europe, the disease agents (pathogens, parasites) and the environmental factors (nutrition, pesticides), are found in LA, but under different conditions or intensities. Diseases are not a major problem, probably due to the genetic background of a little managed bee population and the consequent resistance of the bees, or to the selection of disease resistant bees. Nutrition and pesticides are not a big problem, probably due to a less intensive and less subsidized agriculture in LA compared to industrialized countries. If the colony losses in industrialized countries are the result of a multifactorial effect, then the lack of substantial colony losses in LA may be due to the non-occurrence of this complex effect. In other words, the small scale that characterizes most of agriculture and beekeeping in LA may explain how and why the conditions in the region lead to more sustainable honey bee health.

We consider the situation in LA as a fragile equilibrium because different kinds of risks are becoming more extended. Examples of the risks are: (1) a higher frequency of beekeepers do work with selected queens, but knowledge about disease and mite (mainly Varroa) 
resistance is still insufficient to include desirable traits in queen selection; (2) agriculture is covering more land, pesticides use is increasing and GMOs are becoming more common; (3) natural vegetation is being lost to urban development and increasing crop areas. This situation is particularly true in Argentina, Uruguay and Chile, which seem to be already in an intermediate state of risk for all of the factors, particularly with increasing crop expansion, pesticide and GMO use. As a specific example, in the region of $\mathrm{Mi}$ siones in northern Argentina, beekeeping is practiced at low scale and Varroa treatments are unneeded. In contrast, in the nearby region of NOA, where beekeeping is more intensive (large scale, introduction of queens, intensive crops surrounding), Varroa is more problematic and has to be controlled.

Though speculative, it is possible that a CCD-like phenomenon could happen in LA if principles of sustainability are not immediately included in beekeeping and agriculture development projects. For this reason, the authors of this paper have initiated an informal coordination of research on honey bee genetic diversity and its importance in diseases resistance Latin American (Palacio and Vandame, 2008). Furthermore it would make sense to develop a honey bee health surveillance project together with FAO statisticians, to collect statistics on land use and bee colony losses in LA, to validate the hypotheses suggested in this paper. This project would be important for pollinator diversity conservation and crop production in LA, and more generally for understanding the conditions leading to sustainability.

\section{ACKNOWLEDGEMENTS}

The authors are most grateful to all the persons who gave opinions, ideas, data or papers, and in particular: Emilio Figini, Martín Eguaras and Mariano Bacci (Argentina), Aaroni Sattler, David de Jong, Dejair Message, Erica Weinstein, Katia Peres Gramacho, Lionel Segui Goncalves and Osmar Malaspina (Brazil), Ernesto Guzmán (Canada), Juanse Barros, Misael Cuevas and Miguel A. Neira (Chile), Ana Cubero (Costa Rica), José Ramírez (Ecuador), Niyra Castillo (Dominican Republic),
Roberto Perdomo (El Salvador), Alejandro Nicol (Guatemala), Ernesto Tanús, Luis Medina and Arnulfo Ordoñez (Mexico), Andrés Llaxacondor (Peru) and finally Jorge Harriet, Juan Pablo Campa, Yamandú Mendoza, Karina Antúnez, Pablo Zunino and Ciro Invernizzi (Uruguay). Some of the ideas have been developed as part of the MexicanEuropean FONCICYT 94293 grant "MUTUAL Mutualisms with bees in tropical landscapes: risks and rescue for biodiversity and crop production", which is acknowledged here.

La santé de l'abeille préservée en Amérique latine : un fragile équilibre dû à une agriculture et une apiculture peu intensives?

santé de l'abeille / perte des colonies / résistance aux maladies / diversité génétique / nutrition sur pollen

Zusammenfassung - Gesunde Honigbienen in
Lateinamerika: ein fragiles Gleichgewicht basierend auf der geringen Intensität von Landwirtschaft und Imkerei? Während der letzten Jahre wurden in Europa und den USA mehrfach Verluste von Bienenvölkern (Apis mellifera L.) dokumentiert. Dabei wurden Völkerverluste, die durch den raschen Verlust der Adultbienen hervorgerufen wurden, als "Colony Collapse Disorder" (CCD) bezeichnet. Obwohl sich auf dem lateinamerikanischen Subkontinent einige der größten Honigproduktions- und Honigexportländer der Welt befinden, fehlen bisher klare Dokumentationen über den Gesundheitsstatus der dortigen Honigbienen. Bisher gibt es keine Berichte über massive Völkerverluste in Lateinamerika, zumindest nicht mit CCD-Symptomen oder in dem Ausmaß, wie sie aus Europa und den USA berichtet wurden. Wir prüfen die möglichen Gründe für diese Unterschiede und entwickeln folgende Hypothesen für die Verbreitung ,gesunder Bienen“ in Lateinamerika: (1) es wird meist mit unselektierten Bienen gearbeitet, die über natürliche Krankheitsresistenzen verfügen (tropische Regionen) oder es werden krankheitsresistente Bienen selektiert (gemäBigte Regionen); (2) der Anteil der Agrarfläche am Gesamtgebiet ist relativ gering, wodurch es zu einer ergiebigeren bzw. qualitativ hochwertigeren Pollenversorgung kommt; (3) die allgemein kleinräumig strukturierte Landwirtschaft mit geringem Einkommen und wenig Subventionen führt zu einem geringeren Einsatz von Insektiziden im Vergleich zu den industrialisierten Ländern.

All diese Parameter könnten synergistisch wirken und würden dadurch zu einer großen Anzahl an möglichen Konstellationen innerhalb der enormen ökologischen, sozialen und wirtschaftlichen Vielfalt in Lateinamerika führen. Wir vermuten, dass 
die Gesundheit der Honigbienen in Lateinamerika letztendlich auf die in diesen Regionen vorherrschenden kleinräumigen und wenig intensiven Landwirtschafts- und Imkereistrukturen zurückzuführen ist, da solche Strukturen den Bienen nachhaltigere Lebensbedingungen bieten. Allerdings könnte der Trend zur intensiveren Nutzung der Kulturlandschaft in einigen Teilen Lateinamerikas zu einer Verschlechterung des Gesundheitsstatus der Honigbienen und damit zu einem Rückgang der Bienenpopulation führen. Um diese Hypothese zu überprüfen würde es Sinn machen, zusammen mit der FAO ein Projekt zur Überwachung der Bienengesundheit in Lateinamerika zu etablieren und dabei die für eine statistische Auswertung notwendigen Daten zur Landnutzung und zu Völkerverlusten zu erfassen. Ein solches Projekt wäre auch wichtig für den Erhalt von natürlichen Bestäuberpopulationen und damit für die Sicherung einer nachhaltigen landwirtschaftlichen Produktion in Lateinamerika. Dies würde auch dazu beitragen, die grundsätzlichen Bedingungen für „Nachhaltigkeit“ in tropischen und subtropischen Ländern besser zu verstehen.

\section{Honigbienengesundheit / Völkerverluste / Krankheitsresistenz / genetische Vielfalt / Pollenernährung}

\section{REFERENCES}

Antúnez K., D’Alessandro B., Corbella E., Zunino P. (2005) Detection of chronic bee paralysis virus and acute bee paralysis virus in Uruguayan honeybees, J. Invertebr. Pathol. 90, 69-72.

Antúnez K., D’Alessandro B., Corbella E., Ramallo G., Zunino P. (2006) Honeybee viruses in Uruguay, J. Invertebr. Pathol. 93, 67-70.

Bedascarrasbure E., Figini E., Palacio M.A., Passucci J., Rodríguez E., Poffer D. (2009) American foulbrood control without the use of antibiotics in Argentina. 41st Apimondia Congress, Montpellier, France, 15-20 September 2009.

Behrens D., Forsgren E., Fries I., Moritz R.F.A. (2007) Infection of drone larvae (Apis mellifera) with American foulbrood, Apidologie 38, 281-288.

Brodschneider R., Crailsheim K. (2010) Nutrition and health in honey bees, Apidologie 41, 278-294.

Buechler R., Berg S., Le Conte Y. (2010) Breeding for resistance to Varroa destructor in Europe, Apidologie 41, 393-408.

Carneiro F.E., Torres R.R., Strapazzon R., Ramirez S.A., Guerra J.C.V., Koling D.F., Moretto G. (2007) Changes in the reproductive ability of the mite Varroa destructor in Africanized honey bees (Apis mellifera) colonies in southern Brazil, Neotrop. Entomol. 36, 949-952.
Castillo N. (2009) Dinámica poblacional de Varroa en dos ambientes de la República Dominicana. VI Congreso Centroamericano y del Caribe de Integración y Actualización Apícola, Santo Domingo, Dominican Republic, 24-26 June 2009.

Chen Y.P., Huang Z.Y. (2010) Nosema ceranae, a newly identified pathogen of Apis mellifera in the USA and Asia, Apidologie 41, 364-374.

de Carvalho A.C.P., Message D. (2004) A scientific note on the toxic pollen of Stryphnodendron polyphyllum (Fabaceae, Mimosoideae) which causes sacbrood-like symptoms, Apidologie 35, 89-90.

de Jong D., Gonçalves L.S., Morse R.A. (1984) Dependance on climate of the virulence of Varroa jacobsoni, Bee World 65, 117-121.

de la Rúa P., Jaffé R., Dall’Olio R., Muñoz I., Serrano J. (2009) Biodiversity, conservation and current threats to European honey bees, Apidologie 40, 263-284.

de Souza T.F., Cintra P., Malaspina O., Bueno O.C., Fernandes J.B., Almeida S.S.M.D. (2006) Toxic effects of methanolic and dichloromethane extracts of flowers and peduncles of Stryphnodendron adstringens (Leguminosae: Mimosoideae) on Apis mellifera and Scaptotrigona postica workers, J. Apic. Res. $45,112-116$.

Desneux N., Decourtye A., Delpuech J.M. (2007) The sublethal effects of pesticides on beneficial arthropods, Annu. Rev. Entomol. 52, 81-106.

Duan J.J., Marvier M., Huesing J., Dively G., Huang Z.Y. (2008) A meta-analysis of effects of Bt crops on honey bees (Hymenoptera: Apidae), PLoS One 3, e1415.

EarthTrends (2003) Country profiles, http:// earthtrends.wri.org.

Edwards C.R., Gerber C., Hunt G.J. (2003) A laboratory study to evaluate the toxicity of the Mediterranean fruit fly, Ceratitis capitata, bait, Success 0.02 to the honey bee, Apis mellifera, Apidologie 34, 171-180.

Eyer M., Chen Y.P., Schäfer M.O., Pettis J., Neumann P. (2009) Small hive beetle, Aethina tumida, as a potential biological vector of honey bee viruses, Apidologie 40, 419-428.

FAOSTAT (2009) http://faostat.fao.org.

Fries I. (1993) Nosema Apis - a parasite in the honeybee colony, Bee World 74, 5-19.

Fries I., Bommarco R. (2007) Possible host-parasite adaptations in honey bees infested by Varroa destructor mites, Apidologie 38, 525-533.

Gauthier L., Tentcheva D., Tournaire M., Dainat B., Cousserans F., Colin M.E., Bergoin M. (2007) Viral load estimation in asymptomatic honey bee colonies using the quantitative RT-PCR technique, Apidologie 38, 426-435. 
Guez D., Suchail S., Gauthier M., Maleszka R., Belzunces L.P. (2001) Contrasting effects of imidacloprid on habituation in 7- and 8-day-old honey bees (Apis mellifera), Neurobiol. Learn. Mem. 76, 183-91.

Guzmán-Novoa E., Vandame R., Arrechavaleta M. (1999) Susceptibility of European and Africanized honey bees (Apis mellifera) to Varroa jacobsoni in Mexico, Apidologie 30, 279-287.

Harbo J.R., Harris J.W. (2009) Responses to Varroa by honey bees with different levels of Varroa Sensitive Hygiene, J. Apic. Res. 48, 156-161.

Harriet J., Campa J.P., Mendoza Y., Antúnez K., Zunino P., Invernizzi C. (2009) Situación sanitaria de la apicultura en Uruguay, Techn. Rep., 13 p.

Higes M., Martin-Hernandez R., Meana A. (2010) Nosema ceranae in Europe: an emergent type C nosemosis, Apidologie 41, 375-392.

Ibrahim A., Reuter G., Spivak M. (2007) Field trial of honey bee colonies bred for mechanisms of resistance against Varroa destructor, Apidologie 38, 67-76.

Invernizzi C., Abud C., Tomasco I.H., Harriet J., Ramallo G., Campá J., Katz H., Gardiol G., Mendoza Y. (2009) Presence of Nosema ceranae in honey bees (Apis mellifera) in Uruguay, J. Invertebr. Pathol. 101, 150-153.

Jensen A.B., Pedersen B.V., Eilenberg J. (2009) Differential susceptibility across honey bee colonies in larval chalkbrood resistance, Apidologie 40, 524-534.

Klee J., Besana A.M., Genersch E., Gisder S., Nanetti A., Tam D.Q., Chinh T.X., Puerta F., Ruz J.M., Kryger P., Message D., Hatjina F., Korpela S., Fries I., Paxton R.J. (2007) Widespread dispersal of the microsporidian Nosema ceranae, an emergent pathogen of the western honey bee, Apis mellifera, J. Invertebr. Pathol. 96, 1-10.

Kraus F.B., Franck P., Vandame R. (2007) Asymmetric introgression of African genes in honey bee populations (Apis mellifera L.) in Central Mexico, Heredity 99, 233-240.

Maggi M.D., Ruffinengo S.R., Gende L.B., Eguaras M.J., Sardella N.H. (2009) LC $_{50}$ baseline levels of amitraz, coumaphos, fluvalinate and flumethrin in populations of Varroa destructor from Buenos Aires Province, Argentina, J. Apic. Res. 47, 292295.

Managed Pollinator CAP (2008) A national research and extension initiative to reverse pollinator decline, http://www.beeccdcap.uga.edu.

Mangan R.L., Moreno A. (2009) Honey bee foraging preferences, effects of sugars, and fruit fly toxic bait components, J. Econ. Entomol. 102, 14721481.

Mattila H.R., Otis G.W. (2006) The effects of pollen availability during larval development on the behaviour and physiology of spring-reared honey bee workers, Apidologie 37, 533-546.
Mayrand K., Dionne S., Paquin M., Pageot-LeBel I. (2003) The economic and environmental impacts of agricultural subsidies: an assessment of the 2002 US farm bill and Doha round. Unisféra International Centre, $63 \mathrm{p}$.

Medina-Medina L., May-Itzá W. (2006) The Africanized honey bees and its impact on bee diseases and parasites in Mexico. VII Encontro sobre Abelhas, Ribeirão Preto, Brazil, 12-15 July 2006.

Mondragón L., Spivak M., Vandame R. (2005) A multifactorial study of the resistance of honey bees Apis mellifera to the mite Varroa destructor over one year in Mexico, Apidologie 36, 345-358.

Naug D. (2009) Nutritional stress due to habitat loss may explain recent honeybee colony collapses, Biol. Conserv. 142n, 2369-2372.

Naug D., Gibbs A. (2009) Behavioral changes mediated by hunger in honeybees infected with Nosema ceranae, Apidologie 40, 595-599.

Neumann P., Carreck N.L. (2010) Honey bee colony losses, J. Apic. Res. 49, 1-6.

Palacio A., Vandame R. (2008) Investigaciones latinoamericanas colaborativas sobre la mortalidad de abejas, Workshop in Buenos Aires, Argentina, 8-9 December 2008.

Palacio M.A., Rodríguez E., Gonçalves L., Bedascarrasbure E., Spivak M., Hygienic behaviors of honey bees in response to brood experimentally pin-killed or infected with Ascosphaera apis, Apidologie, in press.

Palacio M.A., Figini E., Rodriguez E., Ruffinengo S., Bedascarrasbure E., del Hoyo M. (2000) Changes in a population of Apis mellifera selected for its hygienic behaviour, Apidologie 31, 471-478.

Palacio M.A., Flores J.M., Figini E., Ruffinengo S., Escande A., Bedascarrasbure E., Rodriguez E., Gonçalves L.S. (2005) Evaluation of the time of uncapping and removing dead brood from cells by hygienic and non-hygienic honey bees, Genet. Mol. Res. 4, 105-114.

Paxton R.J., Klee J., Korpela S., Fries I. (2007) Nosema ceranae has infected Apis mellifera in Europe since at least 1998 and may be more virulent than Nosema Apis, Apidologie 38, 558-565.

Pearce D. (2002) Environmentally harmful subsidies: barriers to sustainable development. Paper presented at the OECD workshop on environmentally harmful subsidies, Paris, 7-8 November 2002, 9.

Pettis J.S., Delaplane K.S. (2010) Coordinated responses to honey bee decline in the USA, Apidologie 41, 256-263.

Piñeyro-Nelson A., Van Heerwaarden J., Perales H.R., Serratos-Hernández J.A., Rangel A., Hufford M.B., Gepts P., Garay-Arroyo A., Rivera-Bustamante R., Álvarez-Buylla E.R. 
(2009) Transgenes in Mexican maize: molecular evidence and methodological considerations for GMO detection in landrace populations, Mol. Ecol. 18, 750-761.

Ramirez-Romero R., Desneux N., Decourtye A., Chaffiold A., Pham-Delègue M.H. (2008) Does $\mathrm{Cry} 1 \mathrm{Ab}$ protein affect learning performances of the honey bee Apis mellifera L. (Hymenoptera, Apidae)? Toxicol. Environ. Saf. 70, 327-333.

Rinderer T.E., Buco S.M., Rubink W.L., Daly H.V., Stelzer J.A., Riggio R.M., Baptista F.C. (1993) Morphometric identification of Africanized and European honey bees using large reference populations, Apidologie 24, 569-585.

Rinderer T.E., Harris J., Hunt G., de Guzman L.I. (2010) Breeding for resistance to Varroa destructor in North America, Apidologie 41, 409-424.

Rose R., Dively G.P., Pettis J. (2007) Effects of Bt corn pollen on honey bees: emphasis on protocol development, Apidologie 38, 368-377.

Rothenbuhler W.C. (1964) Behavior genetics of nest cleaning in honey bees. IV. Responses of F1 and backcross generations to disease-killed brood, Am. Zool. 4, 111-123.

Spivak M., Reuter G. (1998) Performance of hygienic honey bee colonies in a commercial apiary, Apidologie 29, 291-302.
Teixeira E.W., Chen Y., Message D., Pettis J., Evans J.D. (2008) Virus infections in Brazilian honey bees, J. Invertebr. Pathol. 99, 117-119.

Vandame R., Belzunces L.P. (1997) Joint actions of deltamethrin and azole fungicides on honey bee thermoregulation, Neurosci. Lett. 251, 57-60.

Vandame R., Meled M., Colin M.E., Belzunces L.P. (1995) Alteration of the homing-flight in the honey bee Apis mellifera exposed to sublethal dose of deltamethrin, Environ. Toxicol. Chem. 14, 855-860.

Vandame R., Morand S., Colin M.E., Belzunces L. (2002) Parasitism in the social bee Apis mellifera: quantifying costs and benefits of behavioral resistance to Varroa mites, Apidologie 33, 433-445.

van Engelsdorp D., Hayes J., Underwood R.M., Pettis J. (2008) A Survey of honey bee colony losses in the US, fall 2007 to spring 2008, PLoS One 3, e4071.

van Engelsdorp D., Evans J.D., Saegerman C., Mullin C., Haubruge E., Nguyen B.K., Frazier M., Frazier J., Cox-Foster D., Chen Y., Underwood R., Tarpy D.R., Pettis J.S. (2009) Colony Collapse Disorder: a descriptive study, PLoS One 4, e6481.

World Resources Institute (2003) Watersheds of the world: a special collection of river basin data, http://earthtrends.wri.org/maps_spatial/ watersheds/global.php. 